\section{Kidney \\ Blood Pressure Research}

\title{
Troponin I, but not BNP, is Associated with Phosphorus, Calcium and Vitamin D in Stable Coronary Artery Disease
}

\author{
José Pedro L. Nunes
}

Faculdade de Medicina da Universidade do Porto: Center for Research in Health Technologies and Information Systems (Cintesis), Porto

\section{Key Words}

Troponin • Phosphorus • Calcium • Vitamin D • BNP

\begin{abstract}
Background: Elevated plasma cardiac troponin, elevated plasma phosphorus and decreased plasma vitamin D have been shown to be associated with negative outcomes. Methods and results: Troponin I, calcium, phosphorus and $25-\mathrm{OH}$ vitamin D were studied in a cohort of 60 patients with stable coronary heart disease and preserved left ventricular function. Using a cut-off value of $0.012 \mathrm{ng} / \mathrm{mL}$ for plasma troponin I, patients with higher values (18 patients), when compared to the other patients $(n=42)$, had higher mean values for plasma phosphorus $(3.42 \pm 0.45 \mathrm{mg} / \mathrm{dL}$ vs $3.17 \pm 0.45 \mathrm{mg} / \mathrm{dL}, \mathrm{p}=0.041)$ and calcium $(5.08 \pm 0.23 \mathrm{mEq} / \mathrm{L}$ vs $4.92 \pm 0.18$ $\mathrm{mEq} / \mathrm{L}, \mathrm{p}=0.016)$ and lower values for $25-\mathrm{OH}$ vitamin $\mathrm{D}(14.2 \pm 5.6 \mathrm{ng} / \mathrm{mL}$ vs $19.4 \pm 8.8 \mathrm{ng} /$ $\mathrm{mL}, \mathrm{p}=0.032$ ). Binary logistic regression analysis showed that troponin I $>0.012 \mathrm{ng} / \mathrm{ml}$ is associated with increased phosphorus, increased calcium and decreased $25-\mathrm{OH}$ vitamin $\mathrm{D}$ concentrations. A similar analysis using BNP $>100 \mathrm{pg} / \mathrm{mL}$ failed to show significant associations with phosphorus, calcium and $25-\mathrm{OH}$ vitamin D concentrations. Conclusions: In patients with stable coronary artery disease and preserved left ventricular function, those having cardiac troponin I $>0.012 \mathrm{ng} / \mathrm{ml}$, but not those having $\mathrm{BNP}>100 \mathrm{pg} / \mathrm{mL}$, had higher plasma phosphorus, higher plasma calcium and lower plasma $25-\mathrm{OH}$ vitamin $\mathrm{D}$ concentrations than those having cardiac troponin $\mathrm{I} \leq 0.012 \mathrm{ng} / \mathrm{ml}$ (or BNP $\leq 100 \mathrm{pg} / \mathrm{mL}$ ).
\end{abstract}

Copyright $@ 2013$ S. Karger AG, Basel

\section{Introduction}

Plasma cardiac troponin and brain natriuretic peptide (BNP) are major cardiac biomarkers. Cardiac troponin has been shown to be elevated due to myocardial necrosis in myocardial infarction [1], but is also elevated in other acute and chronic settings [2, 3]. Brain natriuretic peptide is a recognized marker for cardiac dysfunction with fluid overload [4]. 


\section{Kidney Blood Pressure Research}

In patients with stable coronary artery disease, plasma cardiac troponin has been shown to be associated with the incidence of cardiovascular death and heart failure, but not with myocardial infarction, [5]. Similar findings were described in a cohort of adults aged 65 years or older without prior heart failure [6].

In a cohort of individuals with prior myocardial infarction, serum phosphate was shown to be associated with total mortality, new heart failure, new myocardial infarction, but not to the risk of stroke [7]. In the Framingham Offspring study, an increased cardiovascular disease risk was associated with serum phosphorus, but not with serum calcium [8].

Low levels of 25-OH vitamin D were shown to be associated with all-cause and cardiovascular mortality [9]. Vitamin D deficiency has been presented as a possible cardiovascular risk factor [10].

In the present report, plasma cardiac troponin I and BNP were studied in a cohort of 60 patients with stable coronary artery disease and preserved left ventricular function, in search for a possible association to plasma phosphorus, calcium and 25-OH vitamin D levels.

\section{Materials and Methods}

A cohort of 60 patients (41 male, 19 female) with coronary heart disease, aged 65.5 years (60.0-73.8; median and interquartile range), was the subject of an observational study. All patients were Caucasian. Patients were observed at an outpatient Cardiology clinic. The study had an observational character.

The research protocol (including the informed consent forms) was evaluated and approved by an independent ethics committee (Comissão de Ética do Centro de Saúde São João, Porto, Portugal), as previously reported [11]. All participants provided a written informed consent, a consent procedure approved by the ethics committee. All consent forms were kept on file. All calculations were made using a database with anonymous data.

Diagnosis was established by coronary angiography, except in one case (with angina, left bundle branch block and suggestive findings in cardiac perfusion imaging). Angiography was performed after myocardial infarction or during assessment of angina pectoris. Exclusion criteria included serious systemic diseases, such as cancer and systemic infections. All patients included in the study had left ventricular ejection fraction, evaluated by echocardiography and/or nuclear scan, greater or equal to $45 \%$.

Patients were evaluated using a protocol which included electrocardiogram, echocardiogram, and plasma levels of creatinine, calcium, phosphorus, $25-0 \mathrm{H}$ vitamin $\mathrm{D}$, cardiac troponin I and brain natriuretic peptide (BNP). Biochemical measurements were performed under routine conditions, immediately after collection of blood and blinded for the other patient characteristics. Additional diagnostic tests were performed if indicated.

Troponin I was measured using the ARCHITECT STAT system, of Abbott Diagnostics (Abbott Park, Illinois, USA). The 99th percentile of troponin I in a normal population with this assay was established at $0.012 \mathrm{ng} / \mathrm{mL}$. All troponin I values $<0.01 \mathrm{ng} / \mathrm{mL}$ (detection limit) were taken as $0.009 \mathrm{ng} / \mathrm{mL}$ for the purpose of calculation.

Estimated glomerular filtration rate (eGFR; $\mathrm{mL} / \mathrm{min}$ per $1.73 \mathrm{~m}^{2}$ ) was calculated according to the (updated) Modification of Diet in Renal Disease (MDRD) study equation: GFR $=175 \times$ (serum creatinine) ${ }^{-1.154}$ $\times(\text { age })^{-0.203} \times 0.742$ (in women) [12] (IDMS-traceable assay) .

\section{Statistical analysis}

Data are presented as either median and interquartile range (whole group) or arithmetic mean and standard deviation (sub-group analysis). Correlations between the various parameters under study were calculated by using the Spearman correlation coefficient $\left(r_{s}\right)$. Pairs of means were compared by using the Mann- Whitney U test. P- values $<0.05$ were considered significant.

Binary logistic regression, taking as dependent variable troponin I (cut-off value at $0.012 \mathrm{ng} / \mathrm{mL}$ ) and as independent variables plasma eGFR, phosphorus, calcium, and 25-OH vitamin D (variables entered in the model in this order), was performed. Statistical calculations were made by using the Statistical Package for the Social Sciences software (SPSS, version 20, IBM Corp., Amonk, NY, USA). 


\section{Kidney \\ Blood Pressure Research}

Table 1. Median and interquartile range for a number of parameters measured in 60 patients with coronary heart disease

Table 2. Plasma values for calcium (mEq/L), phosphorus (mg/dL), 25$\mathrm{OH}$ vitamin $\mathrm{D}(\mathrm{ng} / \mathrm{mL})$ and estimated glomerular filtration rate (eGFR; $\mathrm{mL} / \mathrm{min}$ per $1.73 \mathrm{~m}^{2}$ ), in 60 stable

\begin{tabular}{lcc}
\hline & Median & $\begin{array}{c}\text { Interquartile } \\
\text { range }\end{array}$ \\
\hline Age (years) & 65.5 & $60.0-73.8$ \\
Troponin I (ng/mL) & 0.009 & $0.009-0.014$ \\
Brain natriuretic peptide (pg/mL) & 58.4 & $31.3-106.4$ \\
Phosphorus (mg/dL) & 3.30 & $2.90-3.60$ \\
Calcium (mEq/L) & 5.00 & $4.80-5.10$ \\
25-OH vitamin D (ng/mL) & 17.5 & $12.3-23.5$ \\
Estimated glomerular filtration rate & 83.2 & $66.1-96.8$ \\
(mL/min per 1.73 m2) & & \\
\hline
\end{tabular}
outpatients with coronary heart disease, divided by high and low plasma levels of troponin I and BNP. Data are expressed as means \pm standard deviation. $\mathrm{p}$ - probability ( Mann-Whitney U test)

\begin{tabular}{lcccc}
\hline & $\begin{array}{c}\text { Troponin I } \\
\leq 0.012 \mathrm{ng} / \mathrm{mL} \\
(\mathrm{n}=42)\end{array}$ & $\begin{array}{c}\text { Troponin I } \\
>0.012 \mathrm{ng} / \mathrm{mL} \\
(\mathrm{n}=18)\end{array}$ & $\begin{array}{c}\text { BNP } \\
\leq 100 \mathrm{pg} / \mathrm{mL} \\
(\mathrm{n}=41)\end{array}$ & $\begin{array}{c}\text { BNP } \\
>100 \mathrm{pg} / \mathrm{mL} \\
(\mathrm{n}=19)\end{array}$ \\
\hline Calcium & $4.92 \pm 0.18$ & $5.08 \pm 0.23(\mathrm{p} \mathrm{0.016)}$ & $4.96 \pm 0.19$ & $4.98 \pm 0.25(\mathrm{p} \mathrm{0.83)}$ \\
Phosphorus & $3.17 \pm 0.45$ & $3.42 \pm 0.45(\mathrm{p} \mathrm{0.041)}$ & $3.19 \pm 0.50$ & $3.37 \pm 0.34(\mathrm{p} \mathrm{0.11)}$ \\
25-OH Vitamin D & $19.4 \pm 8.8$ & $14.2 \pm 5.6(\mathrm{p} 0.032)$ & $18.6 \pm 7.5$ & $16.2 \pm 9.9(\mathrm{p} \mathrm{0.25)}$ \\
eGFR & $83.2 \pm 18.0$ & $80.2 \pm 21.4(\mathrm{p} 0.33)$ & $83.7 \pm 16.5$ & $79.4 \pm 23.7(\mathrm{p} \mathrm{0.26)}$ \\
\hline
\end{tabular}

\section{Results}

Median values for the parameters under study are shown in Table 1 . Cardiac troponin I was $\leq 0.012 \mathrm{ng} / \mathrm{ml}$ in 42 patients and even below detection in 34 cases. BNP levels $>100$ $\mathrm{pg} / \mathrm{mL}$ were seen in 19 cases (Table 2).

In the 18 patients having troponin I > $0.012 \mathrm{ng} / \mathrm{mL}$, plasma values of phosphorus, calcium, and 25-OH vitamin D differed significantly from those in the remaining 42 patients (Table 2).

As can be seen in Fig. 1., no plasma troponin I values $>0.020 \mathrm{ng} / \mathrm{mL}$ were seen in patients with a plasma phosphorus $\leq$ to 3.3 $\mathrm{mg} / \mathrm{dL}$, or with a plasma $25-\mathrm{OH}$ vitamin $\mathrm{D}$ level > $20 \mathrm{ng} / \mathrm{mL}$.

Binary logistic regression study, taking troponin I as dependent variable (cut-off level at $0.012 \mathrm{ng} / \mathrm{mL}$ ), and eGFR, calcium, phosphorus and $25-\mathrm{OH}$ vitamin $\mathrm{D}$ as independent variables, yielded significant contributions for phosphorus $(p=0.021)$, calcium $(p=0.026)$ and $25-0 H$ vitamin $D$ $(p=0.026)$, but not for eGFR $(p=0.688)$.

Concerning BNP, no significant difference was seen in the same parameters, however a trend in the same direction was noted for phosphorus (Table 2). Regression study similar to the one described for troponin I yielded negative results (data not shown). Troponin I and BNP were not significantly correlated $\left(r_{s}=0.05, p=0.69\right)$. Troponin I was significantly correlated to calcium $\left(r_{s}=0.31, p=0.02\right)$ and to $25-0 H$ vitamin $D$
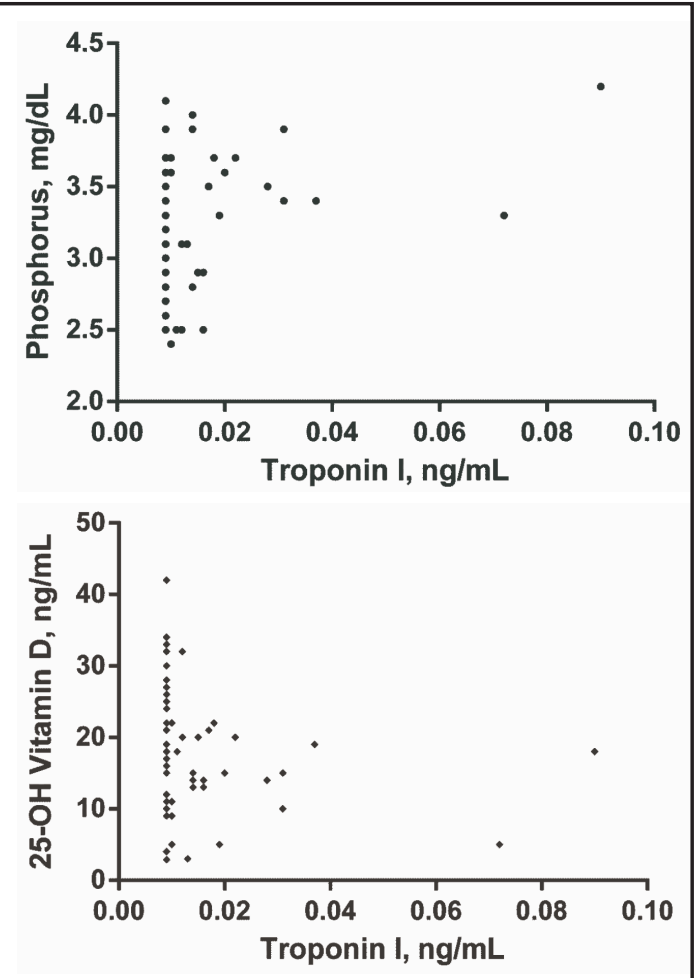

Fig. 1. Relations between plasma phosphorus and cardiac troponin I (top), and between 25-0H vitamin D and cardiac troponin I (bottom) in 60 outpatients with stable coronary artery disease. 


\section{Kidney Blood Pressure Research}

$\left(r_{s}=-0.30, p=0.02\right)$, but not to phosphorus $\left(r_{s}=0.21, p=0.11\right)$. Phosphorus was not significantly correlated to either calcium $\left(r_{s}=-0.02, p=0.88\right)$ or $25-0 H$ vitamin $D\left(r_{s}=0.08, p=0.53\right)$.

\section{Discussion}

In a cohort of 60 patients with stable coronary heart disease and preserved left ventricular function, those having troponin I $>0.012 \mathrm{ng} / \mathrm{mL}$ had higher levels of plasma phosphorus and calcium, and lower levels of $25-\mathrm{OH}$ vitamin $\mathrm{D}$ than those having troponin $\mathrm{I} \leq 0.012 \mathrm{ng} / \mathrm{mL}$. Binary logistic regression analysis also showed an association between troponin I and the three plasma parameters.

Cardiac troponin I plasma levels were initially studied in the context of acute myocardial infarction [1]. However, subsequent research showed that elevated plasma troponin I was often seen in several different acute and chronic contexts, leading to the view that cardiac strain could be the mechanism for increased plasma troponin I in some cases $[2,13,14]$. Hessel et al. [15] showed that intact troponin I can be released from viable cardiomyocytes by stimulation of stretch-responsive integrins. More recently, using a high-sensitivity assay for plasma troponin $\mathrm{T}$, Omland et al. showed that cardiac troponin $\mathrm{T}$ concentrations were significantly associated with the incidence of cardiovascular death and heart failure but not with myocardial infarction in patients with stable coronary artery disease [5]. deFilippi et al. showed incident heart failure and cardiovascular death to be associated with troponin $\mathrm{T}$ values in a cohort of adults aged 65 years or older without prior heart failure [6].

In a cohort of patients with prior myocardial infarction serum phosphate elevations were associated with increased risks of total mortality, new heart failure, new myocardial infarction, but not of stroke [7]. In the Framingham Offspring study, an increased cardiovascular disease risk was shown by Dhingra et al. to be associated with serum phosphorus, but not to serum calcium [8].

On the other hand, Dobnig et al. showed low levels of $25-\mathrm{OH}$ vitamin D to be associated with all-cause and cardiovascular mortality [9].

Phosphate excretion in the kidney is regulated by fibroblast growth factor 23 (FGF-23), interacting with a cofactor, klotho. Kuro-o et al. have shown mutated klotho gene to cause a syndrome resembling human ageing, including a short lifespan, infertility, arteriosclerosis, skin atrophy, osteoporosis and emphysema [16]. Holden et al., studying patients with chronic kidney disease, have shown troponin T to be associated with FGF-23 [17]. In patients with chronic renal failure, serum FGF-23 concentrations were correlated with serum phosphate concentrations [18]. In the present investigation, the hypothesis is raised that deleterious effects of higher phosphorus and/or calcium and of lower vitamin D levels on the heart are reflected by an increase in plasma troponin I. The precise mechanisms underlying this possible association are not yet fully elucidated. Renal insufficiency could be viewed as a possible mechanism, however the data now presented does not support this possibility. An impact of cardiac integrins on mechanisms involving phosphorus/ calcium/ vitamin D [15, 19] would be another theoretical possibility. This phenomenon needs further study in larger samples of individuals both with and without coronary artery disease.

BNP levels were not shown to be associated with phosphorus/calcium/vitamin D in this cohort, leading to the view that volume overload and phosphorus/calcium/vitamin D metabolism could be relatively independent phenomena.

Study limitations - the major limitation of this study is the limited number of patients under study; another limitation, in what concerns calculations with troponin I, is the relatively high detection limit causing undetectable troponin I levels in 34 patients.

\section{Conclusion}

In patients with stable coronary artery disease having preserved left ventricular function, plasma levels of troponin I $>0.012 \mathrm{ng} / \mathrm{mL}$, but not those having BNP $>100 \mathrm{pg} / \mathrm{mL}$, had higher plasma phosphorus, higher plasma calcium, and lower plasma $25-0 \mathrm{H}$ vitamin $\mathrm{D}$ concentrations than those having troponin $\mathrm{I} \leq 0.012 \mathrm{ng} / \mathrm{mL}$ (or BNP $\leq 100 \mathrm{pg} / \mathrm{mL}$ ). 


\section{Kidney \\ Blood Pressure Research}

\begin{tabular}{|c|c|}
\hline \multicolumn{2}{|c|}{ Kidney Blood Press Res 2013;37:43-47 } \\
\hline $\begin{array}{l}\text { DOI: } 10.1159 / 000343399 \\
\text { Published onlıne: March 12, } 2013\end{array}$ & $\begin{array}{l}\text { (c) } 2013 \text { S. Karger AG, Basel } \\
\text { www.karger.com/kbr }\end{array}$ \\
\hline
\end{tabular}

\section{Conflict of Interests}

None.

\section{References}

1 Antman EM, Tanasijevic MJ, Thompson B, Schactman M, McCabe CH, Cannon CP, Fischer GA, Fung AY, Thompson C, Wybenga D, Braunwald E: Cardiac-specific troponin I levels to predict the risk of mortality in patients with acute coronary syndromes. N Engl J Med 1996;335:1342-1349.

2 Nunes JPL: Cardiac troponin I in systemic diseases. A possible role for myocardial strain. Rev Port Cardiol 2001;20:785-788.

-3 Thygesen K, Alpert JS, Jaffe AS, Simoons ML, Chaitman BR, White HD: Third universal definition of myocardial infarction. J Am Coll Cardiol 2012;60:1581-1598.

-4 Yoshimura M, Yasue H, Okumura K, Ogawa H, Jougasaki M, Mukoyama M, Nakao K, Imura H: Different secretion patterns of atrial natriuretic peptide and brain natriuretic peptide in patients with congestive heart failure. Circulation 1993;87:464-469.

5 Omland T, de Lemos JA, Sabatine MS, Christophi CA, Rice MM, Jablonski KA, Tjora S, Domanski MJ, Gersh BJ, Rouleau JL, Pfeffer MA, Braunwald E: A sensitive cardiac troponin T assay in stable coronary artery disease. N Engl J Med 2009;361:2538-2547.

6 deFilippi CR, de Lemos JA, Christenson RH, Gottdiener JS, Kop WJ, Zhan M, Seliger SL: Association of serial measures of cardiac troponin $\mathrm{T}$ using a sensitive assay with incident heart failure and cardiovascular mortality in older adults. JAMA 2010;304:2494-2502.

7 Tonelli M, Sacks F, Pfeffer M, Gao ZW, Curhan G: Relation between serum phosphate level and cardiovascular event rate in people with coronary disease. Circulation 2005;112:2627-2633.

-8 Dhingra R, Sullivan LM, Fox CS, Wang TJ, D'Agostino RB Sr, Gaziano JM, Vasan RS: Relations of serum phosphorus and calcium levels to the incidence of cardiovascular disease in the community. Arch Intern Med 2007;167:879-885.

\9 Dobnig H, Pilz S, Scharnagl H, Renner W, Seelhorst U, Wellnitz B, Kinkeldei J, Boehm BO, Weihrauch G, Maerz W: Independent association of low serum 25-hydroxyvitamin D and 1,25-dihydroxyvitamin D levels with all-cause and cardiovascular mortality. Arch Intern Med 2008;168:1340-1349, 2008.

10 Lee JH, O'Keefe JH, Bell D, Hensrud DD, Holick MF: Vitamin D deficiency: an important, common, and easily treatable cardiovascular risk factor? J Am Coll Cardiol 2008;52:1949-1956.

11 Nunes JPL, Silva JC: Systemic correlates of angiographic coronary artery disease. Plos One 2009;4:e4322.

12 Levey AS, Coresh J, Greene T, Marsh J, Stevens LA, Kusek JW, Van Lente F: Expressing the Modification of Diet in Renal Disease Study equation for estimating glomerular filtration rate with standardized serum creatinine values. Clin Chem 2007;53:766-772.

13 Logeart D, Beyne P, Cusson C, Tokmakova M, Leban M, Guiti C, Bourgoin P, Solal AC: Evidence of cardiac myolysis in severe nonischemic heart failure and the potential role of increased wall strain. Am Heart J 2001;141:247-253.

14 Nunes JPL, Macedo F: An analytical triad for the diagnosis of pulmonary embolism. Cardiology 2000;94:264.

15 Hessel MH, Atsma DE, van der Valk EJ, Bax WH, Schalij MJ, van der Laarse A: Release of cardiac troponin I from viable cardiomyocytes is mediated by integrin stimulation. Pflugers Arch 2008;455:979-986.

-16 Kuro-o M, Matsumura Y, Aizawa H, Kawaguchi H, Suga T, Utsugi T, Ohyama Y, Kurabayashi M, Kaname T, Kume E, Iwasaki H, Iida A, Shiraki-Iida T, Nishikawa S, Nagai R, Nabeshima YI: Mutation of the mouse klotho gene leads to a syndrome resembling ageing. Nature 1997;390:45-51.

17 Holden RM, Beseau D, Booth SL, Adams MA, Garland JS, Morton RA, Collier CP, Foley RN: FGF-23 is associated with cardiac troponin $\mathrm{T}$ and mortality in hemodialysis patients. Hemodial Int 2012;16:53-58.

18 Unsal A, Kose Budak S, Koc Y, Basturk T, Sakaci T, Ahbap E, Sinangil A: Relationship of fibroblast growth factor 23 with left ventricle mass index and coronary calcificaton in chronic renal disease. Kidney Blood Press Res 2012;36:55-64.

19 Brancaccio M, Hirsch E, Notte A, Selvetella G, Lembo G, Tarone G: Integrin signalling: the tug-of-war in heart hypertrophy. Cardiovasc Res 2006;70:422-433. 